\title{
$\left[{ }^{153} \mathrm{Sm}\right]$ Samarium-labeled FAPI-46 radioligand therapy in a patient with lung metastases of a sarcoma
}

\author{
Clemens Kratochwil $^{1}$ (I) $\cdot$ Frederik L. Giesel $^{1} \cdot$ Hendrik Rathke $^{1} \cdot$ Rebecca Fink $^{1} \cdot$ Katharina Dendl $^{1} \cdot$ Jürgen Debus $^{2}$. \\ Walter Mier ${ }^{1}$ - Dirk Jäger ${ }^{3}$. Thomas Lindner ${ }^{1}$. Uwe Haberkorn ${ }^{1,4,5}$
}

Received: 10 February 2021 / Accepted: 18 February 2021 / Published online: 17 March 2021

(C) The Author(s) 2021

\section{Image of the month}

Fibroblast activation protein is overexpressed by cancerassociated fibroblasts (CAFs) in the stroma of several tumor entities and provides anti-immunogenic effects [1]. It can be targeted with radiolabeled small-molecule inhibitors (FAPIs) [2].

This image demonstrates a patient with progression of lung metastatic, fibrous spindle cell soft tissue sarcoma. Primary tumor located between bladder and rectum as well as early generations of oligo-focal metastases had previously been treated by resection and external-beam radiotherapy. In systemic stage, mutanom-based vaccination [3],

This article is part of the Topical Collection on Image of the month

Clemens Kratochwil

Clemens.Kratochwil@med.uni-heidelberg.de

1 Department of Nuclear Medicine, Heidelberg University Hospital, INF 400, 69120 Heidelberg, Germany

2 Department of Radiation Oncology, Heidelberg University Hospital, Heidelberg, Germany

3 Department of Medical Oncology, Heidelberg University Hospital and National Center for Tumor Diseases (NCT),

Heidelberg, Germany

4 Cooperation Unit Nuclear Medicine, German Cancer Research Center (DKFZ), Heidelberg, Germany

5 Translational Lung Research Center Heidelberg (TLRC), German Center for Lung Research (DZL), Heidelberg, Germany cyclophosphamide, and pazopanib had already been used but the patient was considered inappropriate for standard chemotherapy with anthracyclines. An interdisciplinary tumor conference considered experimental FAPI-RLT a promising option for this therapy-refractory patient to serve as a "can opener" for succeeding immunotherapy.

FAPI-PET/CT demonstrated target positive tumor phenotype (a). Due to the relatively short biological tumor halflife of quinoline-based FAPI-46 [1], it was labeled with short physical half-life $(46.3 \mathrm{~h}){ }^{153} \mathrm{Sm}$. Emission scans during therapy demonstrate tumor targeting up to $44 \mathrm{~h}$ p.i. and rapid clearance from normal organs (b). Three cycles with cumulative $20 \mathrm{GBq}{ }^{153} \mathrm{Sm}$ - and $8 \mathrm{GBq}$ Y-90-FAPI-46 $\left({ }^{153} \mathrm{Sm}\right.$ was not available with sufficiently high specific activity) were well tolerated and achieved stable disease for 8 months (c). Next treatment lines were pembrolizumab, experimentally enhanced with oncolytic parvovirus [4], and nab-paclitaxel. Under both therapies, the patient progressed after only 3 months.

One explanation for the clinical activity of ${ }^{90} \mathrm{Y} /{ }^{153} \mathrm{Sm}$ FAPI-46 in this particular case might be FAP expression in both CAFs and sarcoma tumor cells [5], which is unfortunately not the case in other tumor entities. Of course, one case is no proof of general efficacy but obviously this image encourages further studies of FAPI-RLT against soft tissue sarcoma. However, due to technical issues related to ${ }^{153} \mathrm{Sm}$, e.g., regarding specific activity and contamination with ${ }^{154} \mathrm{Eu}$, additional short physical half-life isotopes should be evaluated as alternative options. 
a
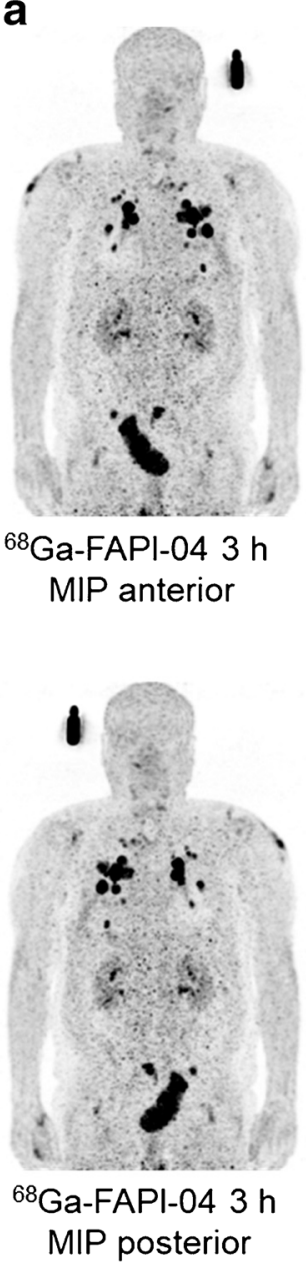

b
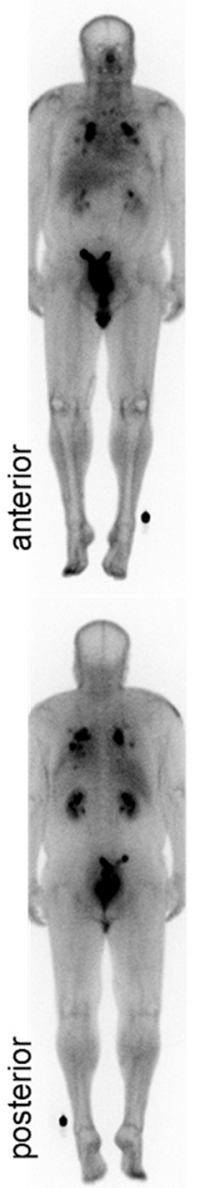

$1 \mathrm{~h}$
${ }^{153} \mathrm{Sm}-\mathrm{FAPI}-46$
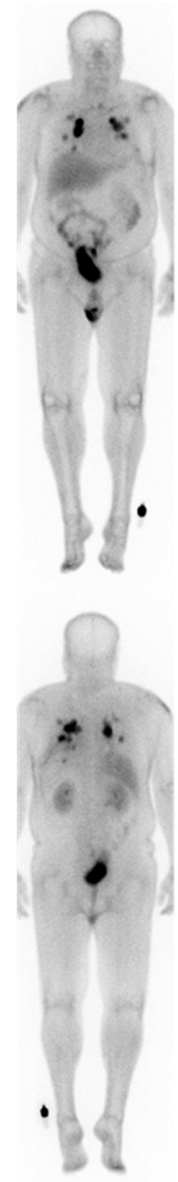

$4 \mathrm{~h}$
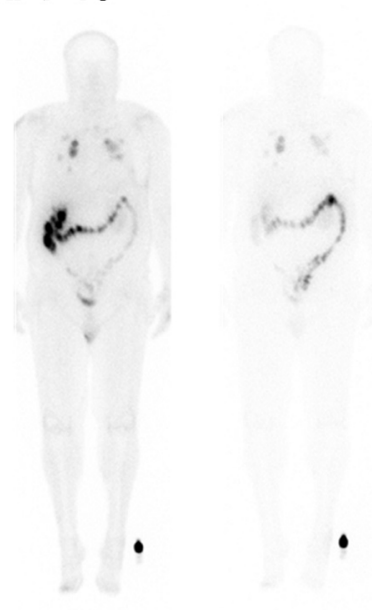

C
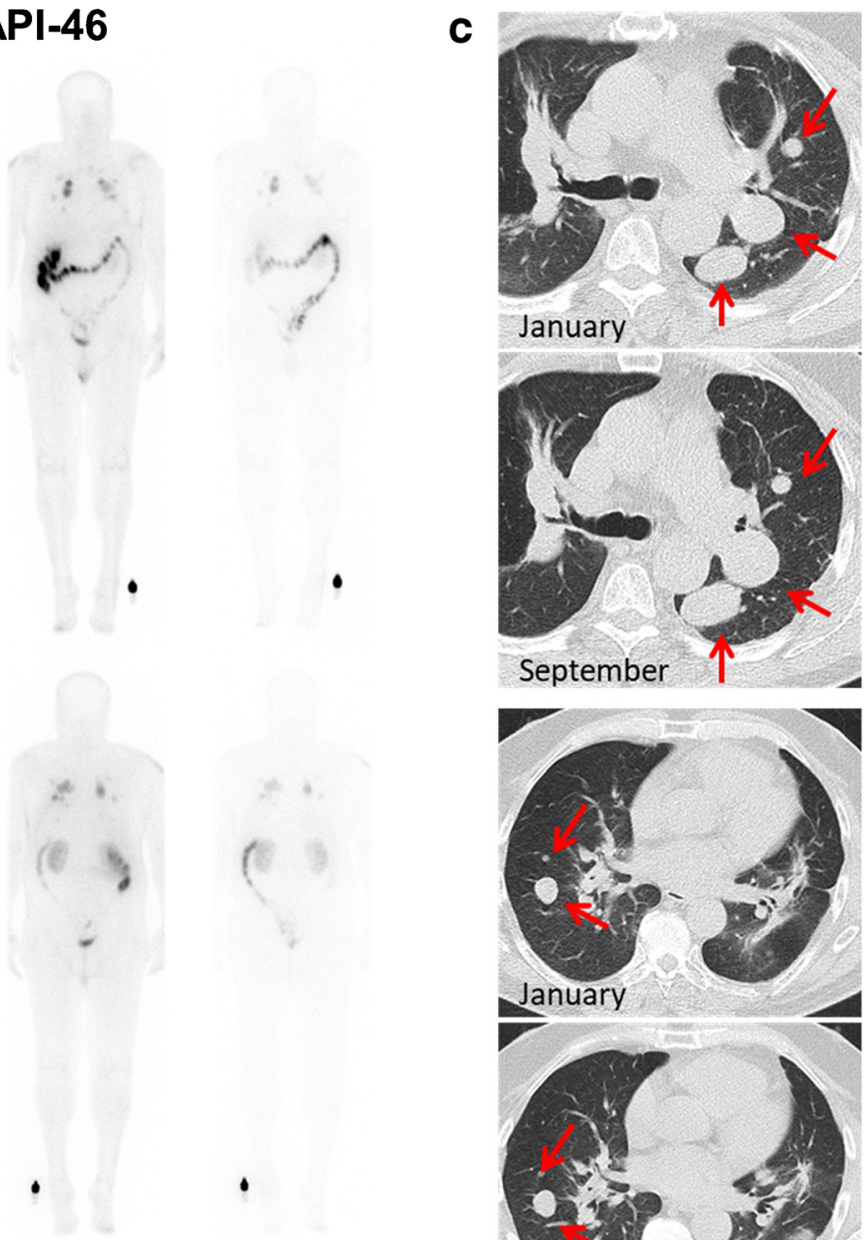

$20 \mathrm{~h}$

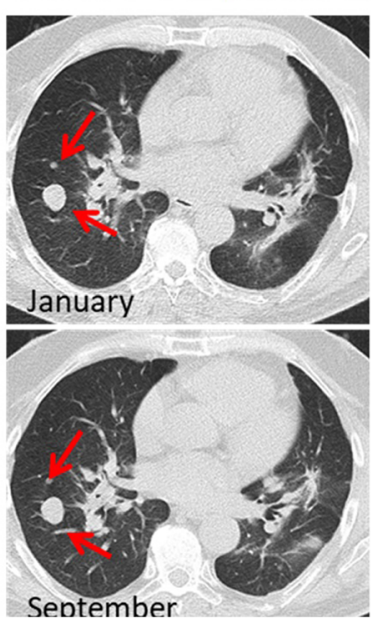

Funding Open Access funding enabled and organized by Projekt DEAL.

Availability of data and material Not applicable

\section{Declarations}

Conflict of interest TL, UH, CK, and FLG have a patent application for FAPI-ligands. TL, UH, CK, and FLG also hold shares of a consultancy for iTheranostics.

Ethics approval This image presents a case report from clinical practice and does not require IRB approval or registration as a clinical trial.

Consent to participate/consent for publication Patient gave written informed consent to receive experimental therapy and anonymized publication of this case.

Open Access This article is licensed under a Creative Commons Attribution 4.0 International License, which permits use, sharing, adaptation, distribution and reproduction in any medium or format, as long as you give appropriate credit to the original author(s) and the source, provide a link to the Creative Commons licence, and indicate if changes were made. The images or other third party material in this article are included in the article's Creative Commons licence, unless indicated otherwise in a credit line to the material. If material is not included in the article's Creative Commons licence and your intended use is not permitted by statutory regulation or exceeds the permitted use, you will need to obtain permission directly from the copyright holder. To view a copy of this licence, visit http://creativecommons.org/licenses/by/4.0/.

\section{References}

1. Liu R, Li H, Liu L, Yu J, Ren X. Fibroblast activation protein: a potential therapeutic target in cancer. Cancer Biol Ther. 2012;13(3): 123-9. https://doi.org/10.4161/cbt.13.3.18696.

2. Giesel FL, Kratochwil C, Lindner T, et al. ${ }^{68}$ Ga-FAPI PET/CT: biodistribution and preliminary dosimetry estimate of 2 DOTAcontaining FAP-targeting agents in patients with various cancers. J Nucl Med. 2019;60(3):386-92. https://doi.org/10.2967/jnumed.118. 215913. 
3. Türeci Ö, Vormehr M, Diken M, Kreiter S, Huber C, Sahin U. Targeting the heterogeneity of cancer with individualized neoepitope vaccines. Clin Cancer Res. 2016;22(8):1885-96. https://doi.org/10. 1158/1078-0432.CCR-15-1509.

4. Ungerechts G, Engeland C, Buchholz CJ, et al. Virotherapy research in Germany: from engineering to translation. Hum Gene Ther. 2017;28(10):800-19. https://doi.org/10.1089/hum.2017.138.

5. Dohi O, Ohtani H, Hatori M, Sato E, Hosaka M, Nagura H, et al. Histogenesis-specific expression of fibroblast activation protein and
dipeptidylpeptidase-IV in human bone and soft tissue tumours. Histopathology. 2009;55(4):432-40. https://doi.org/10.1111/j.13652559.2009.03399.x.

Publisher's note Springer Nature remains neutral with regard to jurisdictional claims in published maps and institutional affiliations. 